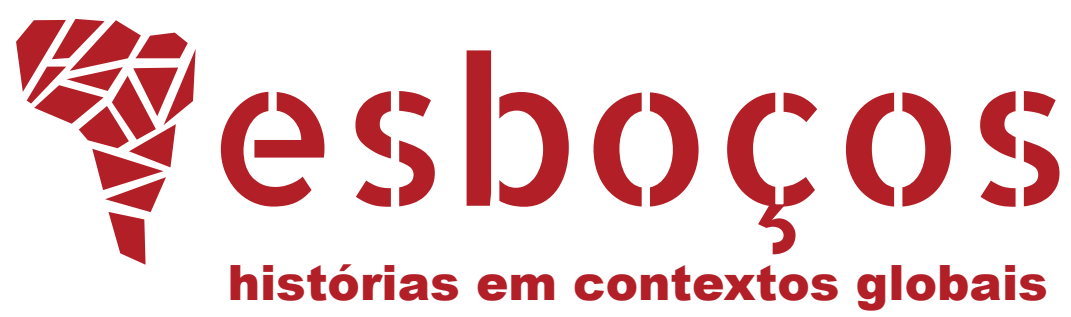

\title{
THE SOCIAL FLOW OF HISTORICAL NARRATIVES AND ITS MANY NAMES
}

Oldimar Pontes Cardoso (1) https://orcid.org/0000-0002-5614-4535 Email: oldimar@gmail.com

a Instituto Brasileiro de Informação em Ciência e Tecnologia, Laboratório em Rede de Humanidades Digitais, Rio de Janeiro, RJ, Brazil 


\begin{abstract}
This paper is a first, partial, and short exposition of a larger research project on the phenomenon of the social flow of historical narratives, which is named for the first time here. It presents a preliminary analysis of four different Western scholar traditions that arose at the end of the twentieth century to understand this phenomenon, although the representatives of these traditions were not completely aware of it: the West German tradition called it Geschichtsdidaktik (History Didactics), the British/Californian/American tradition called it Public History, the Parisian/French tradition called it Lieu de Mémoire (Places of Memory) and the Soviet/Russian tradition called it Социальная Память (Social Memory). This analysis is based on Data Science/Digital Humanities methods related to semantic networks and used Linux and Python scripts to compare these four corpora. The main goal of this project is to present the differences between the official definitions and the semantic-based definitions to help scholars from these fields to think over their tradition on further research. The main conclusion of this study is that, although these four traditions are designed to deal with the same problem (the social flow of historical narratives), the analysis of the semantic networks of their corpora indicates that they have followed completely different paths. We have also noted some inconsistencies between the official discourse of these traditions and their semantic networks, which were described throughout the text.
\end{abstract}

\title{
KEYWORDS
}

Geschichtsdidaktik. Public History. Lieu de Mémoire. 
ike all professionals, many historians want to monopolize the making of their métier socially. But this has never actually happened. Although historians are lalone in the making of historical research, they have always shared the creation of historical narratives with other Erzähler/storytellers (BENJAMIN, 1991) related to popular festivals, monuments, theatre, civic celebrations, schools, literature, museums, memorials, newspapers, magazines, tourism, movies, television, videogames, internet, etc. All these narratives, plus historiography and its interrelations, set what we call here the phenomenon of the social flow of historical narratives. Even if historians think of their work as something better, superior or more scientific, all these other kinds of historical narratives could influence society in a deeper way than historiography, leading to concrete historical consequences. A clumsy historical narrative from a movie seen by millions of people can guide more social action than a scientifically accurate book written by a historian and read by no more than a few hundred peers. That is why these lay historical narratives are socially as important as historiography or maybe even more so, although they are less scientifically rigorous. For historians, for sure, it is very difficult to accept that our narratives are less important than others, but we have to take them into account because we cannot change this reality.

Historical narratives are never isolated. What someone plans for a popular festival was learned in school or seen in a movie; a monument was built based on some civic celebrations or touristic interests; literature influences historiography and vice-versa; videogames take some ideas from movies, which were influenced by magazines and newspapers, which were influenced by television, which borrowed some ideas from a memorial or museum; what we see in a play can come from internet, what we see on the internet can come from a play. Therefore, there is no historical narrative outside its social flow, and the relations between these narratives define this flow. These relations can have some hierarchy or scale of values, but this does not preclude all narratives from playing a role on this permissive flow: less legitimate narratives can influence more people and have a greater impact than accurate ones.

There is no one-way flow from scientific to lay narratives. The flow is bidirectional, as established by the concept of the Wilamowitz effect (CHERVEL, 1998, p. 234, note 5): scientific narratives influence lay narratives, but as the real world includes historians, these lay narratives also influence the way historians think and, therefore, also influence the scientific narratives themselves. One could argue that historians are stringent scientists, immersed in scientific methods to help them escape from the threat of lay thought, but we all know that historians are real people. Underneath the white lab coat, there is always a normal human being: sometimes a prejudiced, corporatist, or proselytizing one. There is no scientific theory or method capable of removing this from any historical analysis. Using the same methods, an old male European historian and a young female African historian could create a different history.

Historical narratives are always, at least, secondary representations in their social flow. This flow is exactly the process that transforms each historical narrative into a new secondary, tertiary, quaternary, etc. historical representation. For example, what a historian learned as a child in school influences his/her work as a historian, which influences a museum exhibit, which influences a TV show, which influences a magazine article or a journal paper and so on. 


\section{GLOBAL PHENOMENON}

The social flow of historical narratives, as described, is not a concept, but a phenomenon. It exists empirically in every global society (and maybe in some nonglobal ones). Western concepts such as Geschichtsdidaktik, Public History, Lieu de Mémoire and Социальная Память ("its many names") were created to handle this phenomenon and to understand the history beyond the historiography. As many Western scientific concepts, they declare themselves universal or global, but they systematically slice the phenomenon they try to make sense of in a limited national way. And the navel-gazing of some Western scholars prevents them from realizing that their merely national standpoint is far from something universal or global.

It is more and more important to understand the social flow of historical narratives in a digital world, especially given the current anti-intellectualism of the post-truth era (KALPOKAS, 2019; PETERS, 2018). During the nineteenth century, historians were close to monopolizing the social flow of historical narratives or, at least, they thought they were. At that time, historians shared historical narratives with no more than historical novels. Their opinion on history was thus very important. During the twentieth century, historians lost the position of major producers of historical narratives to the media, but maintained their relevance and authority in the flow: although the public was consuming narratives other than the scientific ones, they were aware of what historians thought. At that time, the opinion of the historian was the measure of what was historically right or wrong. In the twenty-first century historians are responsible for just a very small portion of historical narratives and, yet, this small part has been discredited by larger audiences the same way science, in general, has, due to the "decline of the scientific culture in the era of fake news" (ELÍAS, 2019).

That is why it is important to focus now on these four traditions: Geschichtsdidaktik, Public History, Lieu de Mémoire, and Социальная Память. Academic historians have lost their singular authority in the present period of anti-intellectualism and they cannot take this authority back by force, claiming to be guardians of the truth and demanding respect of society because of their academic titles. The obscurantist is laughing at the current inconsequence of this kind of discourse and thanking these historians for their ineptitude. Knowing what is true does not help much in a time that prides itself on lies. Many people are unjustly imprisoned today, and discovering evidence of their innocence does not lead them directly to freedom if there is an institutional interest in their imprisonment. Our times require more than truth. A digital society does not need a historian to decide what the truth is: this was the role of the historian in the nineteenth century and this kind of historian is definitively dead. A digital society needs a historian capable of handling multiple lies, hoaxes, fake news, phony facts, and especially able to help society to handle this kind of information. As narratology experts, historians can be the best allies in the war of narratives or lose this war by sticking to their role as guardians of the truth.

But these historians that we so desperately need to fight back anti-intellectualism do not have to start from scratch. These four traditions have lots of interesting experiences on how to handle the social flow of historical narratives, from a time when historiography was still more important than this whole flow. Now, when this flow is more important than historiography, we can use these traditions as a starting point. Answering the title of Elías (2019), these four traditions are the best punch to a "science on the 
ropes," since the kind of anti-intellectualism we have today is not only an opposition to knowledge but intentionally created by systematic actions to "obscure the truth" and engage in the "making of ignorance," when "doubt is their product" (ORESKES, 2010; PROCTOR, 2008; MICHAELS, 2008). As these three authors largely argue, "a handful of scientists" are also contributing to this decline of scientific culture, so this fight does not pit scientists against non-scientists, but rather obscurantism against the spread of knowledge, with scientists and non-scientists in both trenches.

And speaking of this "handful of scientists," we will miss the dead historians from the nineteenth century, our old guardians of historical truth, but not for long. With their safe and stable truth also die their academic harassment, their political control of archives, museums and journals, their symbolic violence, their corporatist view of the social function of history, the imposition of a colonized point of view to the whole world, and the international division of scientific labor: people of color just write their history while white people write the theory of history, the great syntheses, l'Histoire Universelle or the global history (MIGNOLO, 2009, p. 2). The death of the truth-guarding historians is for sure happening within a bad context, with many menaces from obscurantism, but it is also our best chance to decolonize history. The digital methods proposed here are related to open sources (the death of the political control of archives), open methods (the death of academic harassment and symbolic violence), and a way to establish scientific reproducibility in the humanities, which is the long-term target of this whole research project. With open methods, the humanities cease to be a black box - we can trace back every assertion and prove whether it has been accepted through symbolic violence instead of accurate scientific work. In short, after the Digital Transformation, a historian must be more than a selfreferential white man with a good political network to have his/her work published; he/she has to do scientific work. There is no guarantee, however, just a chance. The same Digital Transformation that could set us free from the historians of the nineteenth century and their colonialism could also throw us into "data colonialism," as Nick Couldry and Ulises Mejias define in their forthcoming book The Costs of Connection: How Data Is Colonizing Human Life and Appropriating It for Capitalism.

Since the last quarter of the twentieth century, the rise of non-scientific/ historiological narratives has led some historians to research them. As we can see in Figure 1, such studies have coined many names to explain a part of what the phenomenon of the social flow of historical narratives is: Geschichtsdidaktik, Public History, Lieu de Mémoire, and Социальная Память. As all these traditions have created different concepts to explain the same phenomenon in the same historical period, there are many relations between them, although their authors are often unaware of each other's work. A Venn diagram is used in Figure 1 to explain the nexus of these four traditions. Venn diagrams are used to show all logical relations between a finite collection of different sets. This diagram depicts sets as regions inside closed curves. The social flow of historical narratives is depicted as the only circumscribed circle, in which all the other sets are inscribed. All four traditions (sets) have exclusive relations with each one of the others and also common relations with all of them and other nonrepresented traditions (the set "Other concepts and traditions"). These traditions also have relations with other concepts about the same phenomenon, but not strictly part of each tradition, such as historical imagination, social functions of history, uses of history, mémoire, culture historique, culture historienne, etc., this, however, will not be 
analyzed here. This paper focuses on these four concepts/traditions created at the end of the twentieth century and the possible relations among them.

Figure 1 - The many names of the social flow of historical narratives

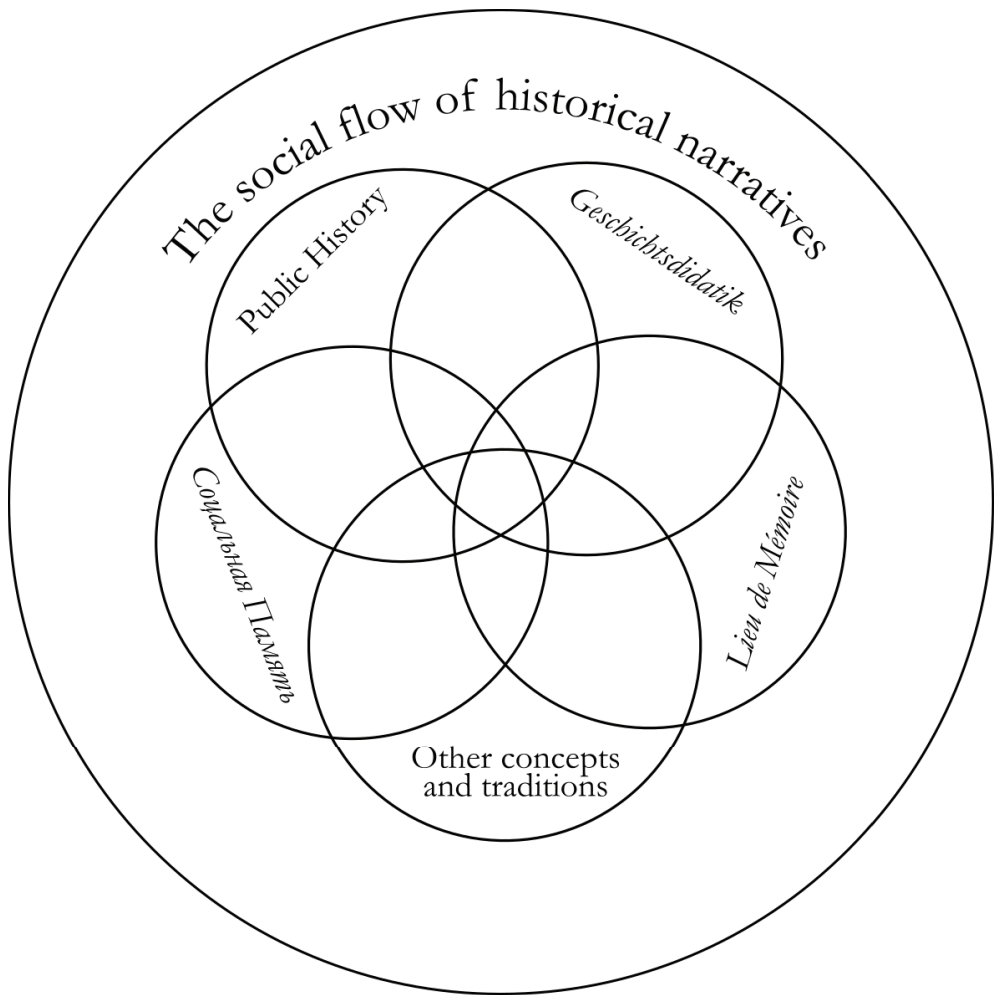

Geschichtsdidaktik is not a translation of what French-speaking authors call Enseignement de l'Histoire or what English-speaking authors call History Education; it represents a completely distinct perspective from these two other traditions. One of the significant differences lies in the fact that Geschichtsdidaktik brings together in a single tradition some phenomena that the other two handle separately. Whereas French and English authors created a tradition to deal with History Teaching (Enseignement de l'Histoire and History Education) and another to deal with the social flow of history (Lieu de Mémoire and Public History), German-speaking authors purposefully approach these two phenomena under the umbrella of Geschichtsdidaktik. French authors have also used the term Didactique de l'Histoire (MONIOT, 1993) since the 1990s, but this expression in French is a mere synonym of Enseignement de l'Histoire. Geschichtsdidaktik was created in West Germany, but it was expanded in the 1970s after meetings with Austrian and Swiss German-speaking historians. The first institution of this tradition was the Konferenz für Geschichtsdidaktik e.V. or KGd, founded in 1973. Walter Fürnrohr (1925-) was the first president of that Society and the International Society for History Didactics (ISHD). The KGd holds biannual scientific conferences and publishes, starting in 2002, the journal Zeitschrift für Geschichtsdidaktik or ZfGd (CARDOSO, 2019, p. 80-81).

In addition to this journal, the knowledge created in this tradition is present in two fundamental works, the Handbook of History Didactics (Handbuch der Geschichtsdidaktik) and the Dictionary of History Didactics (Wörterbuch Geschichtsdidaktik). The Handbook, organized by Klaus Bergmann (1938-2002), 
Anette Kuhn (1934-), Jörn Rüsen (1934-), and Gerhard Schneider (1943-), had different editions published in 1979, 1985 and 1997. The Dictionary, organized by Ulrich Mayer (1941-), Hans-Jürgen Pandel (1940-), Gerhard Schneider, and Bernd Schönemann (1954-), had two different editions published in 2007 and 2014. In Switzerland, the authors of this tradition meet in the Deutschschweizerische Gesellschaft für Geschichtsdidaktik or dggd and, in Austria, at the Gesellschaft für Geschichtsdidaktik Österreich or GDÖ.

The concept of historical consciousness (Geschichtsbewußtsein), as developed by the German philosopher Hans-Georg Gadamer (1900-2002), was defined at the time of the creation of this tradition as its central concept. In the late 1980s, the tradition itself established the concept of historical culture (Geschichtskultur), which considered it as central as that of historical consciousness. This tradition defines itself as

a discipline that asked about the possibility of historical-political education through history lessons, dealing critically and selfcritically with the ideological attunements to which history teaching had been exposed throughout its history to emphasize a critical and socio-critical learning interest to learn from one's history.

Less than 20 years ago, the question of history didactics expanded. Now history didactics was interested in how history is formed and formed in dealing with past and history - not only within the school but also in the "public sphere," in society, in the emerging "media society." It preserved its critical starting point by asking about the risks and dangers of both school and extracurricular ways of dealing with past and history and considering the socio-historical context in which history was presented, conveyed and recorded. [...]

Less than ten years ago, the term "historical culture" emerged as a term for the field of thought and research of history didactics. "Historical culture" was intended to refer to the manifold way in which individuals and collectives deal with history and past - in the media and multimedia, in schools and at the ever-growing number of memorial sites and memorials, at public commemorative events and other occasions of a "culture of remembrance" (BERGMANN, 1997, p. XI, our translation). ${ }^{1}$

\footnotetext{
${ }^{1}$ In the original: "Vor wenig mehr als 30 Jahren entstand die Didaktik der Geschichte als eine Disziplin, die nach der Möglichkeit historisch-politischer Bildung durch den Geschichtsunterricht fragte und sich dabei kritisch und selbstkritisch mit den ideologischen Vereinnahmungen auseinandersetzte, denen der Geschichtsunterricht im Laufe seiner Geschichte ausgesetzt war, entschlossen, ein kritisches, auch gesellschaftskritisches Erkenntnisinteresse zur Geltung zu bringen, um aus der eigenen Geschichte zu lernen. Vor wenig mehr als 20 Jahren weitete sich die Fragestellung der Geschichtsdidaktik aus. Nunmehr zeigte sich die Geschichtsdidaktik daran interessiert, wie im Umgang mit Vergangenheit und Geschichte Geschichtsbewußtsein gebildet wird und sich bildet - nicht nur innerhalb der Schule, sondern, in der "Öffentlichkeit“, in der Gesellschaft, in der sich abzeichnenden "Mediengesellschaft". Sie bewahrte inren kritischen Ausgangspunkt, indem sie zugleich nach den Risiken und Gefahren des schulischen wie des außerschulischen Umgangs mit Vergangenheit und Geschichte fragte und den gesellschaftsgeschichtlichen Kontext mitbedachte, in dem Geschichte präsentiert, vermittelt und aufgenommen wurde. „Eine Disziplin entdeckt ihr Gebiet“, nannte Rolf Schörken den Vorgang. Vor wenig mehr als zehn Jahren tauchte der Begriff der "Geschichtskultur" als Bezeichnung für den Denk- und Forschungsbereich der Geschichtsdidaktik auf. "Geschichtskultur" sollte als Begriff auf die vielfältige Art und Weise des Umgangs von Individuen und Kollektiven mit Vergangenheit und
} 
The Public History tradition started in the USA at the University of California, Santa Barbara, where Robert Kelley created in 1976 a graduate program to train historians on this new subject. The first conferences were in 1978, in Scottsdale, Arizona, and, in 1979, in Montecito, California. The journal The Public Historian was created in 1978, and the National Council on Public History was established in 1979. This tradition spread overseas, especially to English-speaking countries and their cultural colonies. Although The Public Historian is still its main publication, there are many books published in other countries about the subject. The Oxford Handbook of Public History (GARDNER, 2017) is also important to this tradition, which defines itself as something that

encompasses university-based training, the scholarly infrastructure, and the actual work of public historians "in the field," which often results in different perspectives about the term. There has always been a spatial component implied in the term public history. The descriptor public implies that it is "outside" the ivory tower in a space called "the real world," acting as a form of communication among people rather than an individual activity producing history for an author's peers. Although a broader, more capacious concept of its meaning might function as an "umbrella" for a broader range of professional activities, it sometimes frustrates practitioners who want a short, sharp definition such as "work by those who do not choose the historical topic" or the more traditional "practicing history outside the academy". Although they described early understandings of the term "applied history," neither of these definitions now encompasses the activities of many because the field has burgeoned and its purposes have diversified. It is also important to define a field by what it is rather than what it is not, because many people choose to become public historians, rather than seeing that role as a fallback career option to academia.

Moreover, these narrow definitions oversimplify relationships between historians and their clients, collaborators, audiences, and publics, where often the lines are blurred. For example, some public historians working in cultural institutions such as museums or national parks choose their historical subjects in conjunction with others and present new research, sometimes engaging with other scholars in the process; others in the academy move in and out at various times to work on projects, sometimes for an extended period with various publics. Also, some see public history as a livelihood, whereas others view it as a vocation. Those who utilize a range of skills for commissioned projects at companies such as History Works, Inc. (the United States) or Historical Consultants Pty Ltd. (Australia) earn a living from public history. Others feel that assisting communities to do their histories through various forms of advocacy is rewarding political

Geschichte hinweisen - in den Medien und Multimedien, in den Schulen und an den immer zahlreicher werdenden Erinnerungsorten und Gedenkstätten, bei öffentlichen Gedenkveranstaltungen und sonstigen Gelegenheiten einer „Erinnerungskultur"“.”. 
work despite the poor recompense. In Europe particularly, a range of scholars also see public history as a form of public intellectual work whereby their scholarship informs government policies, for example, or assists in the development of historical literacy in schools (GARDNER, 2017, p. 2).

The tradition of Lieu de Mémoire was related to seminars led by Pierre Nora, from 1978 to 1981, at the École des Hautes Études en Sciences Sociales. After these seminars, Nora organized the books Les Lieux de Mémoire between 1984 and 1992. The expression Lieu de Mémoire was included in Le Grand Robert in 1993 and became a common use term. In many other countries, books on their national lieux de mémoire were written: Emmanuel Alcaraz wrote a book on Algerian lieux de mémoire; Etienne François and Hagen Schultze organized three books on the German Erinnerungsorte. This tradition defines itself as something that

includes not only the worship of the dead and the even more expansive concept of heritage, but all the elements that control the economy of the past in the present; and [also] memory, in the sense that it is here understood, is not the opposite of oblivion, which it includes, nor does it identify with remembrance, which it assumes (NORA, 1984, Vol. 1, p. 16, our translation). ${ }^{2}$

The tradition of Социальная Память has as its main author Jaana Rebane (Яана Карловича Ребане), from Tartu, Estonia. It was also established at the end of the twentieth century, from historical research based on the works of the Russian psychologists Aleksei Leontiev (Алексей Николаевич Леонтьев) and Alexander Luria (Александр Романович Лурия). This tradition defines itself as

a concept of "social inheritance," (on the relationship between the social and the biological in a person), the means of accumulating and transmitting social and cultural information. [...]

[It is] accumulated in the course of socio-historical development of information recorded in the results of practical and cognitive activity, passed down from generation to generation through sociocultural means and is the basis of individual self-cognition at each specific stage of historical development (PEБAHE, 1984, p. 3, our translation). ${ }^{3}$

\footnotetext{
${ }^{2}$ In the original: "De cet immense domaine, il était hors de question de faire le tour du propriétaire, puisqu'il ne comprend pas seulement le culte des morts et l'ensemble toujours plus dilaté du patrimoine, mais tous les éléments qui commandent l'économie du passé dans le présent; et puisque la mémoire, au sens où elle est ici entendue, ne s'oppose pas à l'oubli, qu'elle englobe, et ne s'identifie pas au souvenir, qu'elle suppose".

${ }^{3}$ In the original: "В самом широком плане эта концепция имеет значение как концепция о "социальном наследовании", (о соотношении социального и биологического в человеке), о средствах накопления и передачи социально-культурной информации. Социальную память автор характеризует как "накопленную в ходе социально-исторического развития информацию, зафиксированную в результатах практической и познавательной деятельности, передаваемую из поколения в поколение с помощью социокультурных средств и являющуюся основой индивидуального я общественного познания на каждом конкретном этапе исторического развития".
} 
This Soviet tradition was established to understand "the laws governing the formation of a classless structure of society, the internationalization of social life, the development of socialist democracy, the public consciousness, and the problems of communist education" (КОЛЕВАТОВ, 1984, p. 3 , our translation) ${ }^{4}$ It defines that the process of cognition is related to "carriers of social memory" (носители социальной памяти), mediating the human reflection of reality. Although these carriers are constantly present, their presence is usually eliminated in the results of the reflection at the level of knowledge. They are responsible for the "programming" (Программирование) of each person and the implementation process of public knowledge (общественного познания). These carriers are:

1) tools of production and materialized results of labor, often summarized in terms of "material culture" and "second nature";

2) objective social relations, based ultimately on production relations;

3) language in a broad sense, i. e., "natural" languages, their various technical modifications, and extra-linguistic semiotic means (PEБAHE, 1982, p. 7, our translation). ${ }^{5}$

\section{METHODS}

The analysis presented here is a result of the digital comparison of the four corpora described below under the methods established by Silva (2016) and organized in a single algorithm in development, which is presented in Figure 2 and Table 1. This paper will limit itself to a thorough account of the algorithm up to the flowchart's box 9. Decision (in black). The kind of data analysis involved in boxes 10. to 12. deserve detailed explanation, which is impossible here due to space constraints and will, thus, be dealt with in a separate paper.

The methodology used here comes not from "normal science," in the sense that it is not "based upon one or more past scientific achievements, achievements that some particular scientific community acknowledges for a time as supplying the foundation for its further practice" (KUHN, 1996, p. 10). Our intention is not to produce "cumulative" research, but rather the "incommensurable" kind (MARCUM, 2012, p. 42) to answer to "crises," but not those created by an "anomaly," understood as "an experimental or observational failure [...] [or] a phenomenon that resists easy interpretation or classification according to accepted knowledge" (ANDERSEN, 2006, p. 5, 69-72). We consider that the "crisis" we are trying to address is related to Data Science as the next scientific revolution (CAO, 2018, p. 355-356) and its impact on the humanities' paradigms, disciplinary matrix, and exemplars.

\footnotetext{
4 In the original: “закономерностей становления бесклассовой структуры общества, интернационализации социальной жизни, развития социалистического народовластия, общественного сознания, проблем коммунистического воспитания".

5 In the original: "1) орудия производства и овеществленные результаты труда, часто обобщаемые в понятиях «материальная культура» и «вторая природа»; 2) объективные социальные отношения, базирующиеся, в конечном счете, на производственных отношениях; 3) язык в широком смысле, т. е. «естественные» языки, их различные технические видоизменения, а также внеязыковые семиотические средства".
} 
Figure 2 - Metahistory as a flowchart

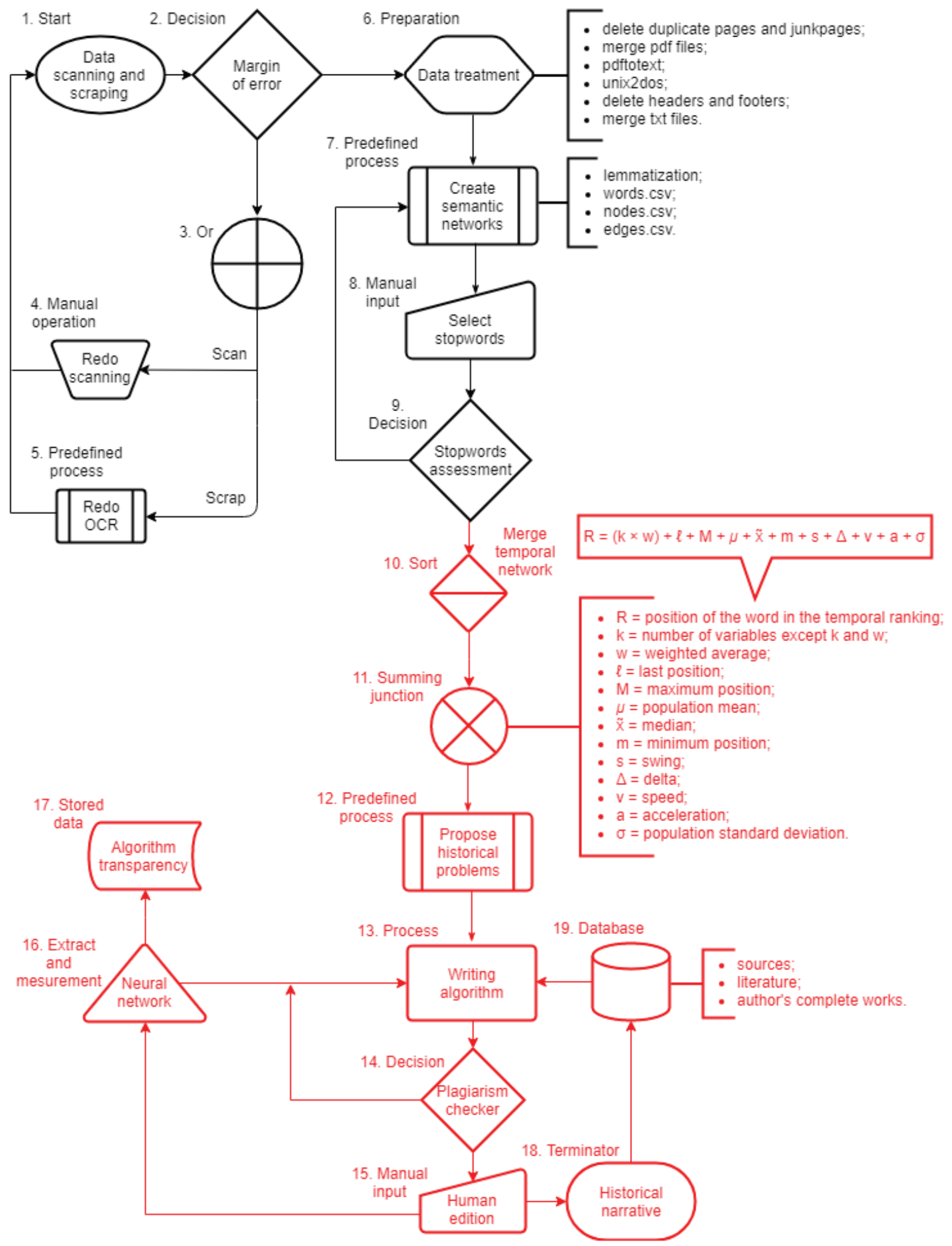


Table 1 - Functions of the first nine boxes of the flowchart

\begin{tabular}{|c|c|}
\hline Box & Functions \\
\hline 1 & $\begin{array}{l}\text { Collection of sources by scanning printed books with some human help or by } \\
\text { automatically scraping data from the internet. The easiest, cheapest, and most } \\
\text { effective way to scan a book, with better results on optical character recognition } \\
\text { (OCR), is to shear its spines and scan it to a portable document format (pdf) file } \\
\text { as single sheets. The first problem with obtaining digital sources is to scrape them } \\
\text { from the internet. As many scholarly platforms have protection against bots, which } \\
\text { is strange and symptomatic, data scraping requires the use of some application } \\
\text { programming interfaces (APIs) to bypass these protections on the platforms where } \\
\text { the sources are stored. After bypassing the protection, the second problem is to deal } \\
\text { with digital files with lousy optical character recognition (OCR) because they were } \\
\text { made a long time ago when this technology was incipient. So we need to delete the } \\
\text { OCRs and generate them again with better technology. }\end{array}$ \\
\hline 2 & $\begin{array}{l}\text { Calculation of the margin of error of the optical character recognition (OCR) used to } \\
\text { digitize the sources. We use a spell-checking tool to know the margin of error of the } \\
\text { digitalization of the sources by counting how many words are detected as wrong by the } \\
\text { tool and comparing this quantity with the number of words in the whole text. If the margin } \\
\text { of error is less than } 1 \% \text {, the data is sent to flowchart box } 6 \text {, "Preparation: Data treatment." } \\
\text { If the margin of error is more than } 1 \% \text {, the data is sent to flowchart box 3, "Or." }\end{array}$ \\
\hline 3 & $\begin{array}{l}\text { The "Or" function, which separates scanned sources, sent to flowchart box 4, "Manual } \\
\text { operation: Redo scanning," from scraped sources, sent to flowchart box 5, "Predefined } \\
\text { sources: Redo OCR." }\end{array}$ \\
\hline 4 & $\begin{array}{l}\text { Manual operation to redo the scanning of printed sources with a margin of error } \\
\text { superior to } 1 \% \text {. It is not possible to do anything automatically if the scanning of a } \\
\text { printed source has been badly done, and this is the only manual operation in this } \\
\text { flowchart that cannot be replaced by an automatic one. }\end{array}$ \\
\hline 5 & $\begin{array}{l}\text { The predefined process to redo the optical character recognition (OCR) if a portable } \\
\text { document format (pdf) file source presents a margin of error greater than } 1 \% \text {. In this } \\
\text { case, we can automatically correct the problem by deleting the old OCR and making } \\
\text { a new one. }\end{array}$ \\
\hline 6 & $\begin{array}{l}\text { Preparation of the sources through data treatment by deleting duplicate pages and } \\
\text { junk pages (such as advertising and tables of contents), merging portable document } \\
\text { format (pdf) files (to combine many articles into just one full edition file), converting } \\
\text { these files to .txt format, converting these files' system from Unix to DOS, deleting } \\
\text { headers and footers from each page (the repetition of the same words on many } \\
\text { pages can skew the final word count and all the results), and finally merging .txt files } \\
\text { to create the corpora of each selected period. }\end{array}$ \\
\hline 7 & $\begin{array}{l}\text { e predefined process to create one semantic network for each corpus. This process } \\
\text { arts with the lemmatization of the corpora, which involves differentiating nouns } \\
\text { id verbs written with the same words and dividing compound words. After that, the } \\
\text { ords of each corpus are counted and ranked in the file words.csv, the nodes formed } \\
\text { these words are identified by one identity number in the file nodes.csv, and these } \\
\text { identity numbers are used to establish the edges between words. }\end{array}$ \\
\hline
\end{tabular}




\begin{tabular}{|c|l|}
\hline 8 & $\begin{array}{l}\text { Manual input of the stopwords, which are the non-relevant words to the research } \\
\text { (such as the, of, and, be, to, etc.), the words used in the title of the source (such as } \\
\text { public and historian in the case of the journal The Public Historian) and in the title of } \\
\text { the field research related to the source (such as the word history in the case of the } \\
\text { journal The Public Historian). The bot can be loaded with a generic list of stopwords } \\
\text { and skip this manual step by automatically filtering the ranking of the most used } \\
\text { words with its default list of stopwords, but manual input provides better quality } \\
\text { until a specific artificial intelligence is developed to define what the stopwords are } \\
\text { in each corpus. }\end{array}$ \\
\hline 9 & $\begin{array}{l}\text { Assessment of whether there are still stopwords among the words in the file words. } \\
\text { csv. If so, the list of words is sent back in a loop to flowchart box 7, "Predefined } \\
\text { process: Create semantic networks;" if not, it is sent to flowchart box 10, "Sort: Merge } \\
\text { temporal network." }\end{array}$ \\
\hline
\end{tabular}

It would be a paradox to argue over the inconsistencies of the official definitions of these four traditions by using their official methods or, as Lorde (2007, p. 111) says, "the master's tools will never dismantle the master's house. They may allow us temporarily to beat him at his own game, but they will never enable us to bring about genuine change." Creating new methods requires "epistemic disobedience" (MIGNOLO, 2009). In this sense, we do not understand Digital Humanities as an auxiliary science of History and its role is not to help historians to make easier and faster use of the same methods they have been using for centuries. The Digital Transformation which is currently underway "is not just about technology;" it is related to technology-driven change, which implies a shift to new ways of working and new methodologies (KOHNKE, 2017, p. 69). This research sees Digital Transformation as the current best chance for epistemic disobedience and wants to contribute to the creation of semantic-based methodologies and to set up the social flow of historical narratives as new paradigms. And both must be done simultaneously.

This paper focuses on the first step of these methods: the comparison of the 20 most used words in each corpus. This particular method may seem trivial to historians. Many of them could disregard the fact that word frequencies can tell more than they think about the essence of a publication or tradition because these methods are new in this field. What these historians ignore is Zipf's Law (ZIPF, 1949; MORENO-SÁNCHEZ, 2016; WILLIAMS, 2016; KANWAL, 2017). This is an empirical law of mathematical statistics, which determines that the frequency of any word in an ordered list is inversely proportional to its rank in the frequency table. This frequency is given by:

$$
f(n)=\frac{K}{n^{\prime}}
$$

where $K$ is a constant. A word is less relevant in a corpus, the more advanced its ranking position is. Most words have very low frequency and play an irrelevant role. The decreasing of the relevance of each word in the ordered list is often logarithmic, rather than linear, so the 20 most used words in a corpus are completely relevant to establish its essence, and no more than this is necessary in most cases. Word counting is not only relevant to the first treatment of the sources in historical research but an essential tool to delegitimize historical speculation without any foundation imposed on the field by mere institutional power. 
Despite the expression "historical narratives" in the title, the aim of this paper is not to compare types of narratives: this would be the next step of this research project. The goal here is to compare four types of concepts/traditions created to describe the same phenomenon called the social flow of historical narratives. These four concepts/ traditions were chosen not because they are the only existing ones in this sense (it could be, we do not know), but because they were the most relevant in imperialistic action, in the sense that they are the traditions most implied in its imposition over cultural colonies around the world. They act for mutual legitimacy: these concepts are relevant because they were replicated by academic branches, and these same academic branches constitute their relevance due to the fact that they are subordinated to some metropolis.

We will not take into account here the historical evolution of these four traditions, their academic change, or progress. It is not possible to consider in a small paper the whole European discourse or the adaption and advancement of the original draft of Nora's Lieu de Mémoire in more than 30 years; the bibliography on Geschichtsdidaktik from other German-speaking countries and the development of the concept in the last 40 years; the whole bibliography on Public History and so on. The relevance of each one of the four corpora inside every tradition is justified below. They represent not a motion, but a snapshot of these traditions. The use of larger corpora, including the whole bibliography of the four traditions or even more traditions, could be the next step of this research.

The first corpus, which was chosen to represent the tradition of Geschichtsdidaktik, was composed by the full text of the Handbook of History Didactics (Handbuch der Geschichtsdidaktik) and the Dictionary of History Didactics (Wörterbuch Geschichtsdidaktik), totaling 41.083 words (BERGMANN, 1997; MAYER, 2014). The collective creation of academic handbooks and dictionaries is a typical attribute of German science. The best way to establish a relevant snapshot of every German academic tradition is to consider first the handbook and the dictionary with the name of the field, and this also applies to Geschichtsdidaktik. There are other handbooks specifically related to media, praxis and methods on Geschichtsunterricht (PANDEL, 2011; BARICELLI, 2012; MAYER, 2016), which are not considered in this piece focused on Geschichtsdidaktik. The spines of these two printed books were sheared, they were scanned to .pdf as single sheets, the full text was recognized by the scanner, the .pdf file was converted into a .txt file using a Linux script and a Python algorithm has cleaned all headers and footers.

The second corpus, which was chosen to represent the tradition of Public History, was composed by the full text of all 156 editions of the journal The Public Historian, from 1978 to 2017, in a total of 848.957 words. This journal is the oldest and the most important in this field, so it is the most relevant publication to choose. An algorithm downloaded all articles from its official website; repeated pages and advertisements were deleted manually; a Linux script added all articles into volumes; editions up to 2001, which had a low-quality OCR (Optical Character Recognition), were deleted and redone by an algorithm; the .pdf files were converted to .txt files and a Python algorithm cleaned all headers and footers.

The third corpus, which was chosen to represent the tradition of Lieu de Mémoire, was composed of the full text of the books Les Lieux de Mémoire, comprising 165.096 words (NORA, 1984-1992). These books are the first on this concept, so they are the most relevant publication to choose as a snapshot. The spines of these three printed 
books were sheared, they were scanned to .pdf as single sheets, the full text was recognized by the scanner, the .pdf files were converted to .txt files using a Linux script and a Python algorithm cleaned all headers and footers.

The fourth corpus, which was chosen to represent the tradition of Социальная Память, was composed of 12 books and articles, seven from Soviet times and five Russian texts from 2006 to 2017, adding up to 30.246 words (БАДРЕТДИНОВ, 2008; КОЛЕВАТОВ, 1984; ЛЕОНТЬЕВ, 1931, 1960; ЛЕВАДА, 1969; ЛУРИЯ, 1974; МИКЛИНА, 2015; РАФИКОВ, 2006; РАГОЗИНА, 2017; РЕБАНЕ, 1982, 1984; СИДОРОВА, 2012). As a Soviet tradition, with sources more difficult to find, the criterion to select its snapshot was just what was still available. Some of these titles were found in digital versions, and some were scanned. The full text was recognized by the scanner and the .pdf file was broken to a .txt file using a Linux script.

With the four corpora in .txt files, a Python code was used to create a list of all words in each corpus organized in decreasing order of the number of times each word appears in the text. The same code also provided one .csv file with nodes and another with edges between all words. The list of words was used to create a list of stopwords. As examples of stopwords, the most used words in each corpus are the, of, end, be, to, in English, le, de, du, et, un, in French, die, un, in, eine, zu, in German, and $8, u, н$, эmom, быть, in Russian. With this list of stopwords, a second code was run to filter each corpus and delete all stopwords and all less significant connections. After that, these nodes and edges files were submitted to the software gephi.org, which created the graphic semantic networks (Figure 3 to Figure 6).

\section{ANALYSIS OF THE CORPORA}

As these four traditions were created at the end of the twentieth century, they have in common an attempt to understand the social flow of historical narratives, notably the role of the non-scientific narratives in this flow. For all of these traditions, it was clear that the Eurocentric metanarratives created in the nineteenth century were no longer sufficient for the postcolonial globe. But each tradition gave different answers to this problem, related to its national contexts.

In the two tables below, we can see the twenty most used words in each corpus, except for the stopwords, which also include the words used in the name of the tradition and the title of the source. In the Public History corpus, the words 'public', 'history,' and 'historian' were considered stopwords; in the Geschichtsdidaktik corpus, just the word 'Geschichtsdidaktik'; in the Lieu de Mémoire corpus, the words 'lieu(x)' et 'mémoire'; in the Социальная память corpus, the words 'Социальная' and 'память.' Each cell of the table below presents the word in the original language, its translation to English, and how many times it appears in the corpus. 
Table 2 - The ten most used words in each corpus, except for stopwords and the words used in the name of the tradition and the title of the source

\begin{tabular}{|c|c|c|c|c|}
\hline & Public History & Geschichtsdidaktik & Lieu de Mémoire & $\begin{array}{c}\text { Социальная } \\
\text { память }\end{array}$ \\
\hline 1 & $\begin{array}{c}\text { American } \\
25.548\end{array}$ & $\begin{array}{c}\text { historisch } \\
\text { historical } \\
3.725\end{array}$ & $\begin{array}{c}\text { France } \\
\text { France } \\
6.337\end{array}$ & $\begin{array}{c}\text { исторический } \\
\text { historical } \\
1.756\end{array}$ \\
\hline 2 & $\begin{array}{c}\text { historical } \\
24.741\end{array}$ & $\begin{array}{l}\text { Geschichte } \\
\text { history } \\
2.973\end{array}$ & $\begin{array}{c}\text { histoire } \\
\text { history } \\
6.118\end{array}$ & $\begin{array}{c}\text { человек } \\
\text { реорle } \\
1.478\end{array}$ \\
\hline 3 & $\begin{array}{c}\text { work } \\
23.235\end{array}$ & $\begin{array}{c}\text { Geschichtsunterricht } \\
\text { history teaching } \\
1.302\end{array}$ & $\begin{array}{c}\text { pouvoir } \\
\text { power } \\
6.110\end{array}$ & $\begin{array}{c}\text { прочесc } \\
\text { process } \\
1.453\end{array}$ \\
\hline 4 & $\begin{array}{l}\text { museum } \\
22.742\end{array}$ & $\begin{array}{c}\text { politisch } \\
\text { political } \\
924\end{array}$ & $\begin{array}{c}\text { français } \\
\text { French } \\
5.439\end{array}$ & $\begin{array}{c}\text { развитиe } \\
\text { development } \\
1.383\end{array}$ \\
\hline 5 & $\begin{array}{l}\text { national } \\
22.615\end{array}$ & $\begin{array}{l}\text { lernen } \\
\text { to learn } \\
829\end{array}$ & $\begin{array}{c}\text { politique } \\
\text { politics } \\
3.299\end{array}$ & $\begin{array}{c}\text { история } \\
\text { history } \\
1.239\end{array}$ \\
\hline 6 & $\begin{array}{c}\text { state } \\
22.036\end{array}$ & $\begin{array}{c}\text { Schüler } \\
\text { pupil } \\
648\end{array}$ & $\begin{array}{c}\text { national } \\
\text { national } \\
3.087\end{array}$ & $\begin{array}{c}\text { наука } \\
\text { science } \\
979\end{array}$ \\
\hline 7 & $\begin{array}{c}\text { university } \\
17.294\end{array}$ & $\begin{array}{c}\text { Geschichts- } \\
\text { wissenschaft } \\
\text { historical science } \\
612\end{array}$ & $\begin{array}{c}\text { roi } \\
\text { king } \\
2.734\end{array}$ & $\begin{array}{c}\text { исследование } \\
\text { research } \\
979\end{array}$ \\
\hline 8 & $\begin{array}{c}\text { park } \\
14.558\end{array}$ & $\begin{array}{c}\text { Unterricht } \\
\text { teaching } \\
609\end{array}$ & $\begin{array}{c}\text { homme } \\
\text { man } \\
2.468\end{array}$ & $\begin{array}{l}\text { система } \\
\text { system } \\
843\end{array}$ \\
\hline 9 & $\begin{array}{l}\text { book } \\
14.475\end{array}$ & $\begin{array}{l}\text { Zeit } \\
\text { time } \\
603\end{array}$ & $\begin{array}{l}\text { état } \\
\text { state } \\
2.448\end{array}$ & $\begin{array}{c}\text { испытуемый } \\
\text { subject } \\
822\end{array}$ \\
\hline 10 & $\begin{array}{c}\text { time } \\
14.378\end{array}$ & $\begin{array}{c}\text { Vergangenheit } \\
\text { past } \\
548\end{array}$ & $\begin{array}{l}\text { temps } \\
\text { time } \\
2.420\end{array}$ & $\begin{array}{c}\text { проблема } \\
\text { problem } \\
768\end{array}$ \\
\hline
\end{tabular}

Table 3 - Words ranked 11-20 in the most used words in each corpus, except for stopwords and the words used in the name of the tradition and the title of the source

\begin{tabular}{|c|c|c|c|c|}
\hline & Public History & Geschichtsdidaktik & Lieu de Mémoire & $\begin{array}{c}\text { Социальная } \\
\text { память }\end{array}$ \\
\hline \multirow{3}{*}{11} & site & sozial & révolution & общество \\
& & social & revolution & society \\
& 13.605 & 543 & 2.200 & 751 \\
\hline \multirow{3}{*}{12} & historic & Formen & société & отношенue \\
& & forms & society & attitude \\
& 13.523 & 538 & 2.145 & 735 \\
\hline \multirow{3}{*}{13} & program & begreifen & ancien & 80прос \\
& & to understand & ancient & question \\
& 13.019 & 538 & 2.022 & 718 \\
\hline
\end{tabular}




\begin{tabular}{|c|c|c|c|c|}
\hline 14 & $\begin{array}{c}\text { war } \\
12.942\end{array}$ & $\begin{array}{c}\text { Deutsch } \\
\text { German } \\
485\end{array}$ & $\begin{array}{c}\text { historique } \\
\text { historical } \\
1.898\end{array}$ & $\begin{array}{c}\text { опыт } \\
\text { experience } \\
710\end{array}$ \\
\hline 15 & $\begin{array}{l}\text { people } \\
12.042\end{array}$ & $\begin{array}{c}\text { Gesellschaft } \\
\text { society } \\
425\end{array}$ & $\begin{array}{l}\text { social } \\
\text { social } \\
1.694\end{array}$ & $\begin{array}{c}\text { задача } \\
\text { task } \\
678\end{array}$ \\
\hline 16 & $\begin{array}{c}\text { research } \\
11.851\end{array}$ & $\begin{array}{c}\text { Problem } \\
\text { problem } \\
399\end{array}$ & $\begin{array}{c}\text { république } \\
\text { republic } \\
1.694\end{array}$ & $\begin{array}{c}\text { общественный } \\
\text { public } \\
677\end{array}$ \\
\hline 17 & $\begin{array}{c}\text { community } \\
11625\end{array}$ & $\begin{array}{c}\text { sinnen } \\
\text { to reflect } \\
399\end{array}$ & $\begin{array}{c}\text { œuvre } \\
\text { artwork } \\
1563\end{array}$ & $\begin{array}{c}\text { связь } \\
\text { communication } \\
668\end{array}$ \\
\hline 18 & $\begin{array}{c}\text { past } \\
11.519\end{array}$ & $\begin{array}{c}\text { didaktisch } \\
\text { didactic } \\
398\end{array}$ & $\begin{array}{c}\text { guerre } \\
\text { war } \\
1.551\end{array}$ & $\begin{array}{c}\text { знание } \\
\text { knowledge } \\
655\end{array}$ \\
\hline 19 & 10.949 & $\begin{array}{c}\text { Geschichts- } \\
\text { bewusstsein } \\
\text { historical } \\
\text { consciousness } \\
396\end{array}$ & $\begin{array}{c}\text { vie } \\
\text { life } \\
1.545\end{array}$ & $\begin{array}{c}\text { деятельность } \\
\text { activity } \\
647\end{array}$ \\
\hline 20 & $\begin{array}{c}\text { preservation } \\
8.903\end{array}$ & $\begin{array}{c}\text { Gegenwart } \\
\text { present } \\
396\end{array}$ & $\begin{array}{c}\text { peuple } \\
\text { people } \\
1.456\end{array}$ & $\begin{array}{c}\text { научный } \\
\text { scientific } \\
639\end{array}$ \\
\hline
\end{tabular}

Figure 3-Graphic representation of the nodes among the most used words on the corpus Geschichtsdidaktik

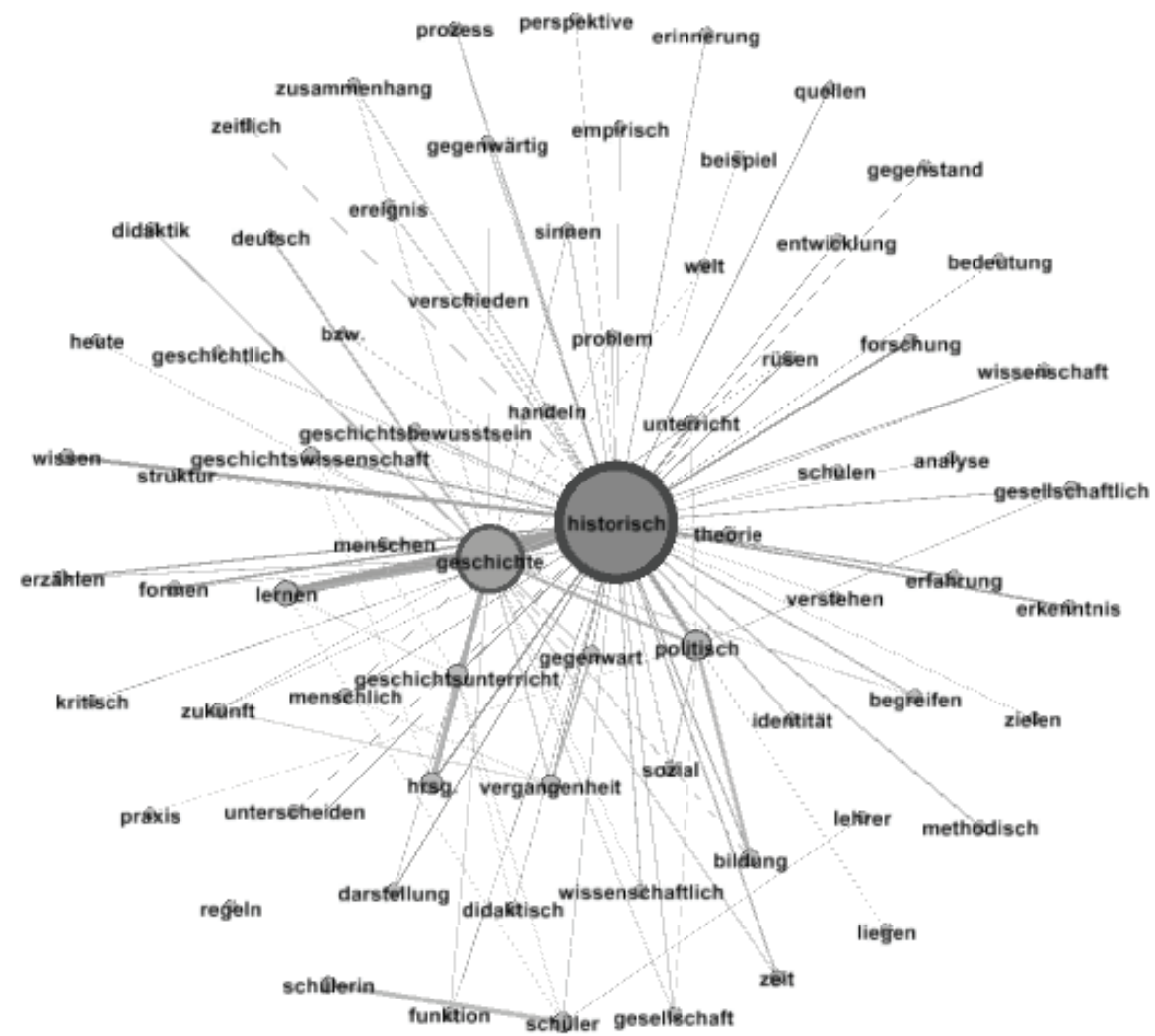


The Geschichtsdidaktik is the only of these four traditions to directly relate the social flow of historical narratives and history teaching in schools. This term (Geschichtsunterricht) is the third most used in this corpus: from a total of 41.083 words, Geschichtsunterricht appeared 1.302 times, more than 3\%. The fact that the words teaching (Unterricht), pupils (Schüler), and learn (lernen) are among the ten most used words in the corpus reinforces this trend. Instead of the focus of this tradition being on school teaching, the role of the historical science (Geschichtswissenschaft) and the Theory of History (Historik) is larger in it than in other history teaching traditions, as History Education and Enseignment de l'Histoire. That is why the word Geschichtswissenschaft is the seventh most used in this corpus. This tradition was created close to the trauma of World War II and it wanted to use school teaching to deal with this past (Vergangenheit), the tenth most used word in this corpus. It is interesting to see that the concept of Geschichtsbewusstsein, considered the most important by the field itself, is only in position 19. This allows us to raise many questions: Why does the field say that this is the most important concept if it is not among the ten most used words? Does it have the relevance the field wants? If not, why does the field do this?

Figure 4 - Graphic representation of the nodes among the most used words on the corpus Public History

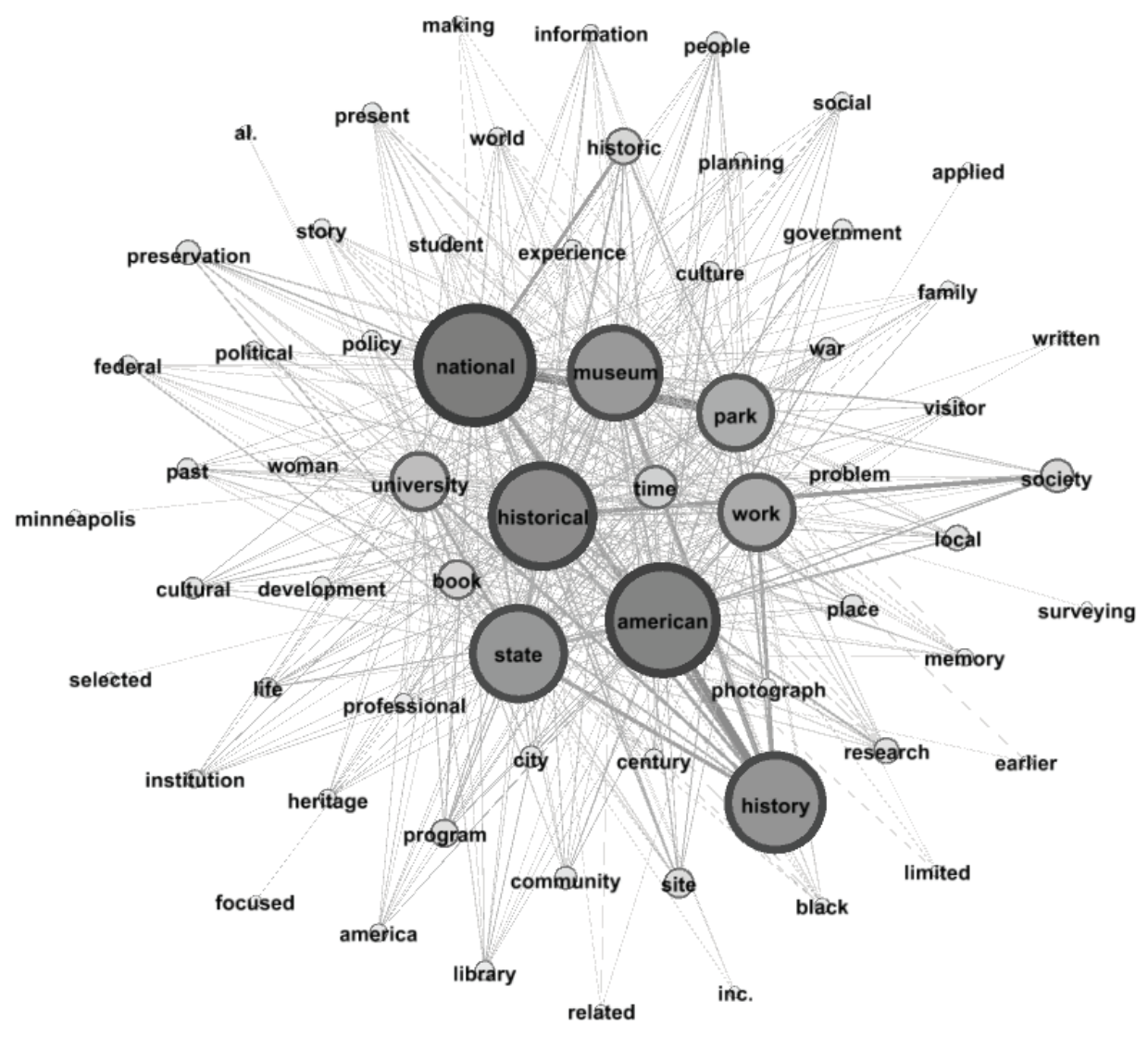

Unlike the previous tradition, Public History is not focused on schools, but on other institutions such as museums and parks, which are the fourth and eighth most used words in this corpus. Maybe this difference is related to the role of public schools in Germany and the USA. The Germans could think of the school as an important actor in the social flow of historical narratives because public schools are the majority 
and the best schools in Germany. In the USA, private schools play a role that probably discourages scholars from thinking of schools as an element of change or, at least, an element capable of massively executing a proposal from the university. Maybe this context can explain the decision not to train history teachers to work in museums and parks, but to create another career to absorb scholars to do this. That is why the word university is the seventh most used in this corpus. This allows us to raise many questions: Why are the words American, national, and state so important? Does this imply some nationalistic and conservative point of view or the exact opposite, a criticism of this kind of conception?

Figure 5 - Graphic representation of the nodes among the most used words in the corpus Lieu de Mémoire

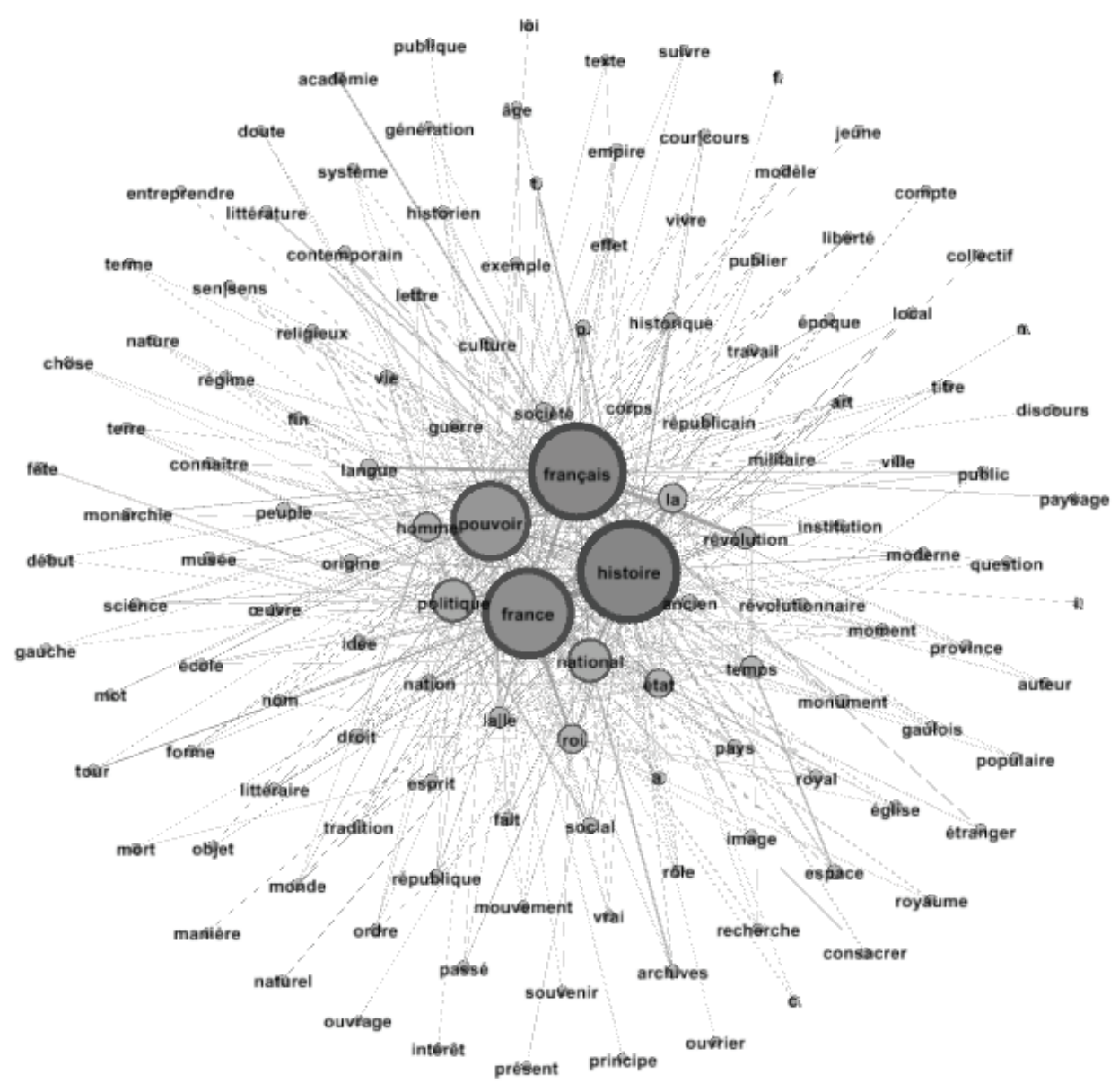

Unlike the two previous traditions, the Lieu de Mémoire is not focused on the use of institutions to deal with the social flow of historical narratives. This tradition is exclusively a scholarly effort to understand this flow without the concern of interacting with it. Instead of the recognition of the existence of non-scientific narratives, the alleged superiority of historiography is preserved by this tradition. This is also apparently a more conservative view of history, with a large role of the king (the seventh most used word in this corpus) and the use of the word man (the eighth most used word in this corpus) as a synonym of a human being. This allows us to raise many questions: Is the use of the word homme (man) as a synonym of a human being sexist? Or is there some criticism to that? Are the words pouvoir (power), national (national), roi (king), 
and état (state) used in a conservative way or exactly the opposite, to criticize this kind of conception?

Figure 6 - Graphic representation of the nodes among the most used words in the corpus Социальная память

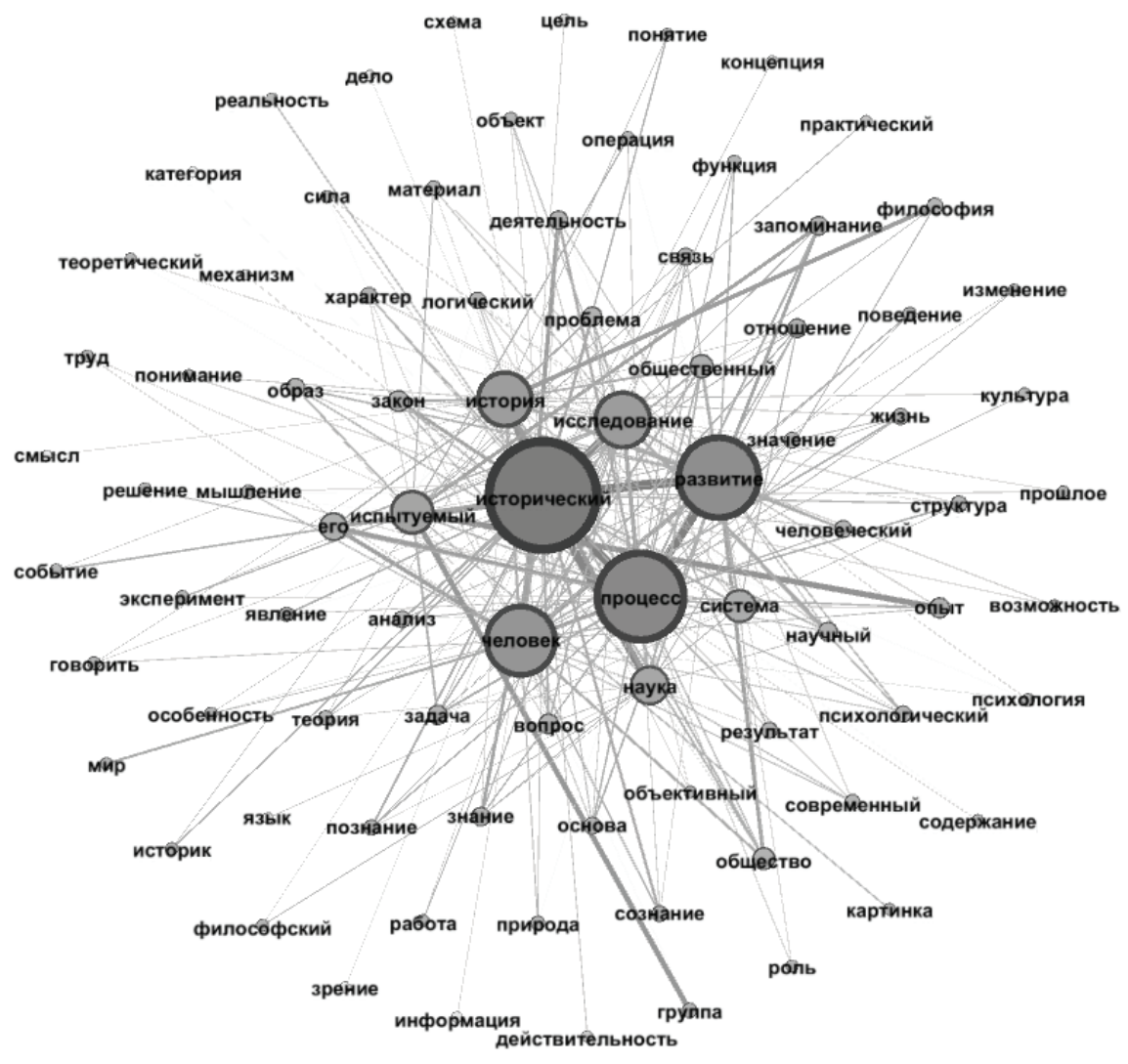

Unlike the three previous traditions, the Социальная память is not focused on institutions like Geschichtsdidaktik and Public History, nor is it just a scholarly effort to understand the social flow of historical narratives like Lieu de Mémoire. The Социальная память was created during the fall of the USSR and was a way to understand how to use history to increase socialist consciousness. And this political motivation directed Soviet scholars to understand History not only as a scientific discipline but also as something used by the collective in everyday life. This allows us to raise many questions: What are the meanings of the words процесc (process), развитue (development), and система (system) in this corpus? Could we find these words in the other three corpora? Do they have similar semantic-networks? Do the words человек (people) and испытуемый (subject) have any connections? Which words have nodes in common with them?

\section{FINAL THOUGHTS}

In conclusion, we propose to define each of the four traditions in just one paragraph, with the ten most used words from each corpus. These four paragraphs are 
written below, with the position of each one of the ten most used words, as presented in Table 2, in parentheses:

Geschichtsdidaktik is a way to think of history teaching (3) based more on historical science (7) than pedagogy, focused on teaching (8) with historical (1) and political (4) purposes, organized to help pupils (6) to learn (5) History (2) in order to deal with time (9) and the past (10);

Public History is a kind of work (3) historians can do beyond the university (7), for example in a museum (4), a park (8), in other state (6) institutions or by writing a book (9) to spread American (1) History to a larger audience in order to help people to deal with time (10) and with historical (2) and national (5) events;

Lieu de Mémoire is a concept created to help France (1) to understand how the king (7) and man (8) make French (4) History (2) through time (10) and how it is related to politics (5), power (3), and the national (6) state (9);

Социальная память is about using historical (1) science (6) to research (7) the problem (10) of the development (4) of history (5) as a system (8), as a process (3) conducted by the people (2) as subjects (9).

These definitions are for sure not the official ones offered by the scholars from each tradition, but the nearest possible definition from the here defined semantic network. All differences between the official definitions and these semantic-based ones can help scholars to think over their tradition on further research.

\section{REFERENCES}

ANDERSEN, H.; BARKER, P.; CHEN, X. The Cognitive Structure of Scientific Revolutions. Cambridge: Cambridge University Press, 2006.

БАДРЕТДИНОВ, В. З. Проблемы Функционирования Социальной Памяти. Вестник КГУ им. Н.А. Некрасова, Кострома, Специальный выпуск, [without volume and number], p. 235-237, 2008.

BARRICELLI, M.; LÜCKE, M. Handbuch Praxis des Geschichtsunterrichts. Schwalbach: Wochenschau, 2012.

BENJAMIN, W. Der Erzähler. Betrachtungen zum Werk Nikolai Lesskows In: BENJAMIN, W. Gesammelte Schriften. Band 2. Teil 2. Frankfurt am Main: Suhrkamp, 1991. p. 438-465.

BERGMANN, K. Handbuch der Geschichtsdidaktik. Seelze-Velber: Kallmeyer, 1997.

CAO, L. Data Science Thinking: The Next Scientific, Technological and Economic Revolution. Cham: Springer, 2018.

CARDOSO, O. Didática da História. In: FERREIRA, M.; OLIVEIRA, M. (coord.). Dicionário de Ensino de História. Rio de Janeiro: FGV Editora, 2019. p. 79-84.

CHERVEL, A. La culture scolaire: une approche historique. Paris: Belin, 1998. 
GARDNER, J.; HAMILTON, P. The Oxford Handbook of Public History. New York: Oxford University Press, 2017.

ELÍAS, C. Science on the Ropes: Decline of Scientific Culture in the Era of Fake News. Cham: Copernicus/Springer, 2019.

KALPOKAS, I. A Political Theory of Post-Truth. Cham: Springer, 2019.

KANWAL, J.; SMITH, K.; CULBERTSON, J.; KIRBY, S. Zipf's Law of Abbreviation and the Principle of Least Effort: Language users optimise a miniature lexicon for efficient communication. Cognition, Amsterdam, v. 165, p. 45-52, 2017.

КОЛЕВАТОВ, В. А. Социальная память и познание. Москва: [s. n.], 1984.

KOHNKE, O. It's Not Just About Technology: The People Side of Digitization. In: OSWALD, G.; KLEINEMEIER, M. (ed.). Shaping the Digital Enterprise: Trends and Use Cases in Digital Innovation and Transformation. Cham: Springer, 2017. p. 69-91.

KUHN, T. S. The Structure of Scientific Revolutions. Chicago: The University of Chicago Press, 1996.

ЛЕОНТЬЕВ, А. Н. Развитие памяти. Москва; [s. n.], 1931.

ЛЕОНТЬЕВ, А. Н. Биологическое и социальное в психике человека. Москва: [s. n.],1960.

ЛЕВАДА, Ю.А. Историческое сознание и научный метод. Философские проблемы исторической науки, Москва, [without volume and number], p. 203213,1969.

LORDE, A. The Master's Tools Will Never Dismantle the Master's House. In: LORDE, A. Sister Outsider: Essays and Speeches. Berkeley: Crossing Press, 2007. p. 110113.

ЛУРИЯ, А. Р. Об историческом развитии познавательных процессов. Москва: [s. n.], 1974.

MARCUM, J. A. From Paradigm to Disciplinary Matrix and Exemplar. In: KINDI, V.; ARABATZIS, T. Kuhn's The structure of scientific revolutions revisited. New York: Routledge, 2012.

MAYER, U. Wörterbuch Geschichtsdidaktik. Schwalbach: Wochenschau, 2014.

MAYER, U. Handbuch Methoden im Geschichtsunterricht. Schwalbach: Wochenschau, 2016.

MICHAELS, D. Doubt is their product: how industry's assault on science threatens your health. London: Oxford University Press, 2008. 
МИКЛИНА, Л. И. Социальная Память Современной Российцкой Молодежи. Власть, Москва, v. 23, п. 1, р. 136-140, 2015.

MIGNOLO, W. Epistemic Disobedience, Independent Thought and De-Colonial Freedom. Theory, Culture \& Society, Los Angeles, London, New Delhi, and Singapore, v. 26, n. 7-8, p. 1-23, 2009.

MONIOT, H. Didactique de l'Histoire. Paris: Nathan, 1993.

MORENO-SÁNCHEZ, I.; FONT-CLOS, F.; CORRAL, Á. Large-Scale Analysis of Zipf's Law in English Texts, PLoS ONE, San Francisco/Cambridge, v. 11, n. 1, 2016. DOI: https://doi.org/10.1371/journal.pone.0147073. Acesso em: 19 jul. 2019.

NORA, P. Les Lieux de Mémoire. Paris: Gallimard,1984-1992.

ORESKES, N.; CONWAY, E. M. Merchants of Doubt: How a Handful of Scientists Obscured the Truth on Issues from Tobacco Smoke to Global Warming. New York: Bloomsbury Press, 2010.

PANDEL, H.-J. Handbuch Medien im Geschichtsunterricht. Schwalbach: Wochenschau, 2011.

PETERS, M. A. et alii. Post-Truth, Fake News, Viral Modernity \& Higher Education. Cham: Springer, 2018.

PROCTOR, R.; SCHIEBINGER, L. Agnotology: The Making and Unmaking of Ignorance. Palo Alto: Stanford University Press, 2008.

РАФИКОВ, А. М. Социальная Память И Механизмы Ее Воспроизводства. Вестник Башкирского университета, Уфра, [without volume], n. 2, 2006.

РАГОЗИНА, Т. Э. Культурная Память Versus Историческая Память. Наука. Искусство. Культура, Белгород , v. 3, n. 15, р. 12-21, 2017.

РЕБАНЕ, Я. К. Информация и социальная память: к проблеме социальной детерминации познания. Вопросы фолософрии, Москва, [without volume], n. 8, 1982.

РЕБАНЕ, Я. К. Принцип социальной памяти. Тарту, 1984.

СИДОРОВА, Л. О. Концептуальные Подходы К Понятию Историческая Память. Вестник Мгуки, Москва, v. 4, n. 48, р. 81-86, 2012.

SILVA, E. A.; SILVA, J. M. Ofício, Engenho e Arte: Inspiração e Técnica na Análise de Dados Qualitativos. Revista Latino-americana de Geografia e Gênero, Ponta Grossa, v. 7, n. 1, p. 132-154, 2016.

The Public Historian. Vol. 1, 1978 - Vol. 39, 2017. 
WILLIAMS, J. R.; BAGROW, J. P.; REAGAN, A. J.; ALAJAJIAN, S. E.; DANFORTH, C. M.; DODDS, P. S. Zipf's law is a consequence of coherent language production. arXiv, Ithaca, https://arxiv.org/abs/1601.07969v2, 2016.

ZIPF, G. K. Human Behavior and the Principle of Least Effort. Cambridge: AddisonWesley, 1949.

\section{NOTES}

\section{AUTHOR DETAILS}

Oldimar Pontes Cardoso: PhD. Researcher, Instituto Brasileiro de Informação em Ciência e Tecnologia, Laboratório em Rede de Humanidades Digitais, Rio de Janeiro, RJ, Brazil.

\section{CORRESPONDING ADDRESS}

Rua Gregório Paes de Almeida, 1090, 05450-001, São Paulo, SP, Brazil.

\section{ACKNOWLEDGEMENTS}

Acknowledgements to Edson Armando Silva, Cynthia L. Z. DeRoma and Marco Costa.

\section{FUNDING}

Not applicable.

\section{ETHICS COMMITTEE APPROVAL}

Not applicable.

\section{CONFLICT OF INTEREST}

There is no conflict of interest.

\section{LICENSE OF USE}

This article is licensed under the Creative Commons License CC-BY. With this license, you can share, adapt, create for any purpose, as long as the authorship is properly attributed.

\section{PUBLISHER}

Universidade Federal de Santa Catarina. Graduate Program in History. UFSC Journal Portal. The ideas expressed in this article are the sole responsibility of its authors, and do not represent, necessarily, the opinion of the editors or the University.

\section{EDITORS}

Alex Degan

Beatriz Mamigonian

Fábio Augusto Morales

Flávia Florentino Varella (Editor-in-Chief)

Tiago Kramer de Oliveira

Waldomiro Lourenço da Silva Júnior

\section{HISTORY}

Received on: Mar. 032019

Approved on: July 182019

How to cite: CARDOSO, Oldimar Pontes. The Social Flow of Historical Narratives and its Many Names. Esboços, Florianópolis, v. 26, n. 43, p. 573-596, set./dez. 2019. 